\title{
Shifts in the European Discourses on Migration and Development
}

\author{
Ernst Spaan \\ Netherlands Interdisciplinary Demographic Institute \\ Ton van $\mathbf{N}$ aerssen \\ Radboud University Nijmegen \\ Felicitas Hillmann
}

Free University of Berlin

The issue of migration and development is currently high on the agenda of both development agencies and research institutes in several European countries. It used to bediscussed during the 1960/ 1970s within a framework which, among others, comprised push-and pull factors in migration, brain drain, remittances and return migration. Its return on the development agendaoccurs within thecontext of European post-modern societies, gl obalization and transnationalism. Key notions now are remittances and foreign direct investment, knowledge transfer, brain gain, transnational entrepreneurship and diasporas.

This paper aims to explain the shifts in paradigms and discourses, with reference to the European Union, and particularly in the Netherlands and Germany. Research efforts and policy documents were scrutinized to trace the shifts in discourses. Moreover, the role of different actors in the debategovernment agencies, migrant organizations, development funding agencies, and research institutes- is explored. Although somecomparisonswere madewith similar situations in other parts of theworld, the paper focuses on Asia-Europe migration. Although the migration and development debate hasacquired amorepositivetone, therecognition of thepotential of diasporas for development varies by country context and pol icies haveyet to integrate migration and development issues in their frameworks. 


\section{Introduction}

The relationship between migration and development has re-emerged on the agenda of researchers and policymakers dealing with development issues. Governments, multilateral agencies, NGOs, academics and migrant diasporashavejoined thedebateon themigration-developmentnexus(Van Hear and Nyberg-Sorensen, 2003; Hugo, 2003). ${ }^{1}$ While the impacts of migration on the development process of migrant sending countries in the developing world had been acknowledged for quite sometime, thejury is out as to whether migration has a positive or negative impact on development. What has been notable is the shift from a rather pessimistic tone to a more optimistic appraisal in recent years.

According to Papademetriou and Martin (1991:5; 14) pastanalysis of the effects of migration on the development of sending countries has been erroneously narrowed down to a single element, such as brain drain or migrants' remittances, thereby glossing over the multidimensional nature of the development process. ${ }^{2} \mathrm{~A}$ lthough theseissuesstill figureprominently, other themes are now under consideration. Framed within the new paradigm of transnationalism, such themes include circular migration, brain circulation, skill formation (Wicramasekara, 2003), migrant entrepreneurship (A muedo-Dorantes et al., 2003, A mmassari, 2004), transnational philanthropy (Opiniano, 2002), and the role of return migrants (Black et al., 2003).

Despite possible analytical pitfalls of transnationalism, e.g., methodological national ism or theglossing over of class differences and theimportance of national regulations (Wimmer and Glick Schiller, 2003; Waldinger and Fitzgerald, 2004), this new paradigm has firmly linked development with processes of globalization and global technological advances. Guarnizo (2003) postulates that the existence of transnational communities, with a driveto reproducetheir socio-cultural practices abroad, stimulates business in the country of origin. The migrant diaspora is an extended national market and offers ample opportunities to create transnational businesses and joint ventures. They can generatesignificant multi-directional flows of

\footnotetext{
${ }^{1}$ Theterm "diaspora" isused herein abroad senseaswefind itnow in theliterature. Itrefers to theexistence of communities living abroad. Weareaware of the looser and watered-down use of the term since it had for many years a religious connotation and was also part of geopolitical argumentation (see Lacoste, 1989)

${ }^{2}$ Development subsumes issues such as sustainable environments, food security, female empowerment, political empowerment, democratic values, health and education etc.
} 
commodities, capital, skills and ideas, contributing to social, political and cultural linkages, in addition to economic impacts.

This paper aims to clarify the shifts in discourses on migration and development and to bring out the contrasts in experiences and thinking about the theme. In the following sections, we will first discuss migration and development on a more general theoretical level, after which policies and programsin theEU aresuccinctly reviewed. An exposeof theDutch and German debates follows, dealing with the main actors at the policy-level and the empirical evidence that is reflected in academic debates.

\section{The Changing Discourse on M igration and Development}

Within thespace of this articlewecannot do justiceto thevast literatureand variety of theoretical approaches, rather, werestrictourselves to pointing to some basic notions underlying the debate. ${ }^{3}$ Two contrasting theoretical approaches formulated several decades ago exemplify the basic notions that inform the thinking on the migration-development theme.

The first is the 'balanced growth approach' as represented by Kindleberger (1965), and Griffin (1976). This approach, rooted in neo-liberal economic theory, posits net positive effects of out-migration for the regions/ country of origin. The emigration of (surplus) labor from underdeveloped, peripheral areas leads to a new equilibrium between capital and labor that eventually fosters development. This line of reasoning emerged within the context of high demand for unskilled labor in Western Europe and theburgeoning labor forces in developing regions in the south (Martin, 1991:29). Kindleberger (1965) acknowledges possi blenegative effects, such as direct loss of skilled labor and loss of production. Buttheseareconsidered short-term and the positive factors outweigh the negative ones in thelong term. A mong themajor argumentsis theidea that out-migration leads to an improvement in resource availability and income distribution in origin areas. Sincemigrant labor is surpluslabor or easily replaceable, thereareno major production losses. Atthemacro and microlevels, remittancescontribute to a more favorable balance of payment situation, fosters consumption and investment and improves the well-being of migrants households. Moreover, economic growth can accelerate through incoming investment capital and by the application of returning migrants skills and ideas.

\footnotetext{
${ }^{3}$ For discussions of thetheoretical literaturein the field of migration and development we refer to Martin (1991), Massey et al. (1998), Binford (2003); Van Hear and Nyberg-Sorensen (2003).
} 
During the late 1970 s and 1980s the second approach, the contrasting 'asymmetrical growth approach,' gained ground (A badan-U natetal., 1975; Penninx and Van Velsen, 1977; Martin, 1991). The basic assumption is that there is a link between underdevelopment in migrant sending regions and development in receiving regions. This is manifested through an unbalanced distribution of benefits and resources, which is reinforced through migration. A mong others, this approach argues that migration is selective and deprives the origin areas of their young, healthy, productive and innovativeworkforce, subsequently resulting in changes in production and a loss in productivity. Furthermore, the return benefits from the investments in human capital by the origin countries are foregone. As return migration also includes those returning due to failure, illness or old age, it does not contribute to productivity. Skill formation of migrants is limited due to the nature of employment at the destination and acquired skills are incompatible to the production systems in origin areas. This approach also argues that remittances are insufficiently geared towards productive investment, but rather fuel consumption and price inflation and a greater dependency on remittance income. Finally, at the community level, migration fosters greater socio-economic differentiation and social inequality.

In the 1980s and early 1990s the tone of the debate on migration and development was still rather pessimistic. Papademetriou and Martin's (1991) influential study is emblematic: they concluded that migration has rarely contributed significantly to economic take-off in origin areas. Therefore Martin (1991:28) asserts that policies should stimulate the maximization of benefits from remittances and the skills of return migrant, instead of assuming that they will automatically contribute to development within emigration regions.

However, the1990ssaw ashift towardsamoreoptimisticdiscourseand morestudiesemphasizing thepositiveimpact of international migration, in particular in relation to the impact of remittances for the local economy in the areas of origin. It is argued that even consumptive expenditure of remittances has positive multiplier effects, stimulating productivity and employment. Given the poor, marginalized origins of migrants, earnings from international migration reduce income disparities across class, regional and rural-urban lines (Binford, 2003).

The World Bank Global Development Finance report (2003) gave this positivestance more clout, by pointing to the large increase in remittances in the 1990s, which even superseded the total official development assistance of devel oped countries. Remittances are considered as an alternative form of (investment) capital for devel oping countries (Ratha, 2003). Thereis also a growing awareness that "remittances" encompass morethan money transfers alone. As the president of the Inter-A merican Foundation (IAF) 
cogently stated "We have learned that remittances are not just financial transfers but include "remittances" of new ideas and practices(for instance, citizen participation or the role of women) and "remittances" of new skills and experiences (for instance, construction techniquesor computer applications) that can also betransferred to the "home-town" communities" (IAF, 2003).

The on-going academic discussion on transnationalism has widened the perspective on the connections between migration and development. Transnational ism advances that migration is not a unidimensional process but rather entails the maintenance of multi-stranded economic and noneconomic relationships between homeand host countries. This framework contributed to a morepositiveviewpoint in thecurrent migration-development debate. In thepast therewas concern over thenegativeeffects of braindrain, translating into policiesai med at restricting theemigration of highlyskilled manpower, exacting compensation, or, alternatively, attempting to retain these people through incentives. Currently, the debate is more balanced and weighs the pros and cons of the emigration of skilled and professional manpower (Lowell and Findlay, 2002; Wickramasekara, 2003).

Moreover, there is more awareness of the potential to benefit from the highly-skilled diaspora - parts of the discourse narrowed down to the privileged group of migrants. Capitalizing on thediasporafor development purposes can be done through, e.g., the facilitation of return migration or involving the diaspora through circulation, business networking, virtual return and information exchange. A good exampleis theThai ReverseBrain Drain project started in 1997 under theauspices of theN ational Scienceand Technology Development Agency of Thailand (NSTDA ). ${ }^{4}$ Migrants' skills, networks and financial resources/ remittances should be mobilized to promotecapacity building, technology transfer and privateinvestments (IOM, 2003).

Thus, brain drain can evolveinto what has been coined "brain-gain," or even "brain circulation" (Hugo, 2003), if expatriates areenticed to (temporarily) return home, or, when theexchange of knowledge, investments and business cooperation is facilitated through circulation. ${ }^{5} \mathrm{~A}$ striking example is that of expatriate IT workers in Silicon Valley fostering the development of businesses in India and China (Saxenian, 2000; H unger, 2002). It is crucial to create an enabling environment where opportunities for investments,

\section{${ }^{4}$ See the Reverse Brain Drain project's website: http:/ / rbd.nstda.or.th/ index.html}

${ }^{5}$ On the role of the highly qualified migrants in the transformation process of Eastern Europe, see Rudolph and Hillmann (1998). 
innovation and business creation are maximized. Emigration of skilled workers can al so have positive spin-off effects in terms of remittances and astimulusto follow and investmorein higher education, thereby enhancing the human capital resources.

A part from involvement in business, returning migrants al so have a role to play in the transformation of domestic political and administrative systems through their newly acquired skills, ideas and authority. Skeldon (2004:16), for instance, notes that return migrants are important players in the parliaments of Asia's new industrialized countries. The influence of returning nationals in domestic politics and government is also manifest elsewhere, for instance, as exemplified by thePhilippineOverseas A bsentee Voting Law, passed in 2003.

Next to stressing thepositive role of remittances and the brain gain, the discourse shift pays attention to the role of migrant diasporas in development. The migrant diasporas can beinvolved in local development efforts, without necessarily returning permanently to the country of origin. This could also include second and third generation migrants, for whom the "country of origin" is rather the country of their forebears. Furthermore, diasporas arebecoming moreand moreactivein advocacy, networking and projects aimed at involvement of their countries of origin. ${ }^{6}$ Theinvolvement of the diaspora also takes place in disaster and (post-)conflict situations whereby migrants in the diaspora pool funds for relief or reconstruction efforts, e.g., in Sri Lanka and Indonesia (Cheran, 2003; Steijlen, 2004).

As has been articulated by different observers (Wickramasekara, 2003), optimizing theinvolvement of the diaspora, including transnational entrepreneurs would presuppose the facilitation of circular migration. This, however, runscounter to thetendency of developed countries governments to implement restrictive policies towards population movement and immigration. Skeldon (2004:6) points out that immigration polices are not reconcilable with more flexible labor recruitment regimes, e.g., GATS mode $4,{ }^{7}$ but in the short term, seem to leave room for the mobility of certain categories of migrants, such as intra-corporate transferees, highly-skilled service workers, entrepreneurs and trainees.

\footnotetext{
${ }^{6}$ The number of diaspora networks are quite numerous and involve many regions and nationalities. Hugo (2003) provides examplesfor A siawhileTurner etal. (2003) listsfifty-seven diaspora networks in ten A sian countries including networks of ICT professionals, engineers and physicians.

${ }^{7}$ M ode 4 of the General Agreement on Trade in Services (GATS), in forcesince 1995, refers to the movement in natural persons, i.e., a person travelling to supply services in another country (see Lavenex, 2004).
} 
For a more balanced assessment of the benefits of migration for the development of sending countries, we also need to take into account the social costs entailed by migration. International migration often implies the separation of spouses, disrupted families, children having to cope without parents, increased inequality and friction in communities and considerable psychological strain on migrants and those left behind. Moreover, the current trend in feminization of migration al so implies a higher vulnerability to exploitation and (sexual) abuse (IOM , 2004d; Wets, 2004).

\section{Linking M igration and Development in European Policy}

In Europe, the thinking about the relationship between migration and development was mainly framed in the context of return flows of former guest workers and asylum seekers. During the late 1970s and 1980s, when economic recession hit the European economies and guest-worker migration was put to an end, governments became more aware of the economic effects of migration for both immigration and emigration countries. Economic restructuring, rising unemployment and social tensions brought about a policy orientation towards return migration, translating into indirectmeasuressuch asquotasystemsor temporary residencepermits(France, Bel gium, N etherlands), or more direct incentives to foster return migration (Germany, Belgium, Netherlands).

Nevertheless, there was some concern over theeffect of massivereturn migration of redundant workers in terms of labor market reintegration (Tassello, 1986:126). This instigated a report by the Organisation for Economic Co-operation and Development (OECD) on migration, growth and development (Kindleberger, 1978), that called for devising appropriate mechanisms for the reintegration of migrants and supporting employment generation projects in origin countries. The N etherlands' experience with the Reintegration of Emigrant Manpower and Local Opportunities for Development (REMPLOD) project in 1977, which is discussed in a latter section, provides insights into policy issues.

In recent years the debate on the migration-development nexus has widened beyond theeconomic dimension and acknowledges themultifarious linkages between the countries of origin and destination. N evertheless, repatriation and reintegration arestill importantelements in European migration policies, although they do not necessarily address devel opment issues in the long term. Assisted voluntary return (AVR) programs have increasingly been seen as a viable option, as suggested by theincreasing number of AVR programs. In 1979 only Germany had such a program called Remigration and Emigration for Asylum Seekers in Germany (REAG); in 2004, 20 AVR programs were implemented by 18 European countries, 
including the Netherlands, the United Kingdom and Austria (IOM , 2004a; Black and Koser et al., 2004). The voluntary return programs aim to facilitate the permanent return of legal and unauthorized migrants by reintegrating thereturnees socially and economically in theorigin community. Thus, it fits thepolicy aim of many programs to limit futuremigration flows (OCIV, 2001).

Return migration is potentially a means of contributing to the development of countries of origin. Theassumption is that migrantsacquireknowledge, skills and capital in the receiving countries that can be used productively in their country of origin upon their return. ${ }^{8}$ However, thesuccessful application of thesehuman, social and financial resourcescan behampered by all kind sof constraints, including an unfavorableeconomicenvironment, unstable political and security situation, lack of institutional support, inefficient bureaucracy, corruption, inadequatecapital markets, local competition or a mismatch of skills. Therefore, several prerequisites are necessary for return migration to contribute to local development efforts. Moreover, the active participation of (local) government and other stakehol ders in the country of origin is necessary in the planning and implementation phases.

At present the different EU countries still lack a clear, integrated and uniform policy in the field of return migration, reintegration and development (A GEF, 2004). Although many return and reintegration programsare implemented by various governmental and non-governmental organizations, these programs are carried out independently of each other and without clear coordination. In a number of countries - e.g. Spain, Greece, Italy and Ireland - the issue is almost absent on the political agenda. Only Denmark and the Netherlands have special laws on return migration. Hitherto, thenumber of countries that have managed to forgea strong link between return, reintegration and (local) development in the countries of origin arestill few. ${ }^{9}$ Theset-up of such programs requiresmorecoordination across relevant government departmentsand developing an adequatelegal basis, taking into account the different legal statuses of themigrants and the variety of origin country contexts.

Morerecently, theroleof diasporas in development projects becamevisible, not the least because of the efforts of migrant organizations. A major

\footnotetext{
${ }^{8}$ Early initiativestaken in thisfield areUNDP's'Transfer of Know-how Through Expatriate Nationals' (TOKTEN) program started in 1976 and IOM's 'Return of Qualified African Nationals' program carried out during 1983-1999 (Trotzki and Schuman, 2002:50).

${ }^{9}$ Some countries have piloted programs that foster development, such as support for business start-ups. For details, see European Reintegration Networking: http:/ / www.reintegration.net/ laender/ index.htm
} 
initiative was the Euro-M oroccan conference in Tangiers (1996), which led to a number of meetings and conferences in Morocco and Europe on migration and devel opment, and ultimately to theEuro-M oroccan network on Migration and Development in 2002. ${ }^{10}$ From the viewpoint of governmental aid agencies, however, privatedevelopment projectstaken up by the diaspora are not embedded in a well thought out general development strategy and may lack a firm professional basis. On theother hand, migrant organizations and NGOs can view these attempts at integrating diaspora activities with formal development aid as unnecessary since they consider themselvescapableof running theprogramsin an efficientand autonomous way. In the Dutch debate, as discussed below, many small-scale diaspora organizations involved in development projects have articulated distrust about state intervention; for this reason, they maintain separate aid initiatives. Thetwo channels are not usually compatiblein that official developmentaid mostly targetsthepoorest peopleand areas, whilemigrantsarenot necessarily from the poorest strata or countries.

M igration and development aid now also figure in the European debate. Governments have attempted to promote development as a means to alleviate the adverse conditions causing underdevelopment and conflict, whileatthesametimereducing propensitiesfor migration to Europe. In this respect, theFrench policy of co-devel oppement, instigated after 1997, servesas a kind of model. It attempts to forge a link between immigration (control) with development processes in sending countries. It built on al ready established transnational development initiatives by the African diaspora in France. The policy advocates possibilities for temporary immigration for (vocational) training or facilitation of business creation, next to more conventional measures such as repatriation support. It specifically aims to involve regional state agencies, migrants' associations and business and professional networks. The rationale is that by boosting development in countries of origin, migration pressures will be reduced.

This policy spurred considerable debate at the national and EU levels and remains controversial for some, particularly because of its (supposed) connection with immigration control (A umüller, 2004a). In 2001 the European Commissioner for Justice and Home Affairs A ntonio Vitorino advocated a co-development policy that ensures "migrants have possibilities of moving on or going back as thesituation develops in their country of origin and elsewherein theworld...[including] innovativeideas to encouragethe voluntary return of migrants ....in a framework of supported reintegration in countries of origin...[and] reduce the negative factors associated with

${ }^{10}$ At present around two million Moroccans are living in Western Europe. 
emigration and ensure longer term benefits, particularly for developing countries" (M igration N ews, 2001).

However, various consultations with agencies such as ILO and OECD and submission of proposals on the issue have yet to be translated into coherent, comprehensive migration-oriented and development aid policy. According to Aumüller (2004b), this is due to a lack of research and knowledgeon theissue. Moreover, devel opment aid agencies are rel uctant to execute policies with the underlying motive to stem (the alleged or real) massinflux of refugees, asylum seekersand economicmigrants. Thelinking of development aid with migration policy remains contentious (Baschle, 2004), and to a certain extent, it is a sensitive issue in the development cooperation circles.

Nevertheless, on a higher level, the EU has taken first steps to forge a stronger link between the migration and development policies. A decade ago theEuropean Commission (EC) signal ed theneed for morecooperation with migrant sending countries in a bid to reduce migration pressure on Europe. But it was only in 2002that theCommission publicized a document specifically addressing thetheme of migration and development (EC, 2002). The EU underscored the necessity of integrating migration issues in its relations with third countries, including a more harmonized migration admission policy that takes theinterests of theEU and sending countriesinto account. AttheEuropean Council meeting in Seville, Spain inJune2002, the EC decided to include actions on the joint management of migration flows and readmission of unauthorized migrants(EC, 2003a: 39). Theconclusions reached at the EC meeting hinted at a reevaluation of relations in cases of countries that do not show sufficient cooperation in the fight against unauthorized migration.

Migration in general is to be integrated into a comprehensive external policy of the EU, linking migration and development issues. It is increasingly recognized that the reduction of international migration cannot berealized only by restrictiveimmigration policies, but that theconditions in theorigin countries in the developing world also need to improve. This implies fostering progress in human rights and conflict prevention, economic conditions and the labor market, food security, health and the environment.

Thus, a moreintegrativeEU policy was announced in 2002 that should not only address the management of migration flows and host country integration issues, but also the root causes of migration, repatriation of immigrants and asylum-seekers, reintegration of migrants in origin countries and the promotion of the role of the diaspora in the development (cf. EC, 2004c). The latter implies the more efficient and productive mobilization of financial resources and strengthening transnational communication facilities of migrantcommunities. Tothesecould beadded measuresaiming 
at fostering "brain-gain" through repatriation of skills, fostering circulation of highly skilled labor between European and developing countries, and refraining from harmful recruitment of professionals in short supply in developing countries (EC, 2002, 2003b, 2005).

In March 2004, the Council of the European Union and European Parliament officially adopted a program for financial and technical assistanceto third countries in theareas of migration and asylum (AENEAS). The EU aimsto intensify cooperation al ongathree- pronged strategy: 1) tackling root causes of migration; 2 ) integrating migration issues in the political dialogue with a focus on unauthorized as well as on channels for legal migration, and 3) integrating migration in development cooperation programsto improvethecapacity of developing countriesto managemigration flows (EC, 2004b:46). However, thus far, theemphasis in their regional programsstill lies on migration management, countering unauthorized migration and border enforcement. Diaspora efforts in development are also acknowledged. EC regulation N o. 491/2004does explicitly mention theEC support for actions by third countriesaimed at fostering themaintenanceof linkages between the diaspora and their communities of origin and facilitating their contributions to local social and economic development (EC, 2004b).

\section{Asia-Europe Migration}

N ext to theeconomic importance of the A sian region for Europe, migration flows from A sia to Europe haveincreased in recent years and have become more diverse in terms of nationalities and types of migrants. N ot only are flows of asylum-seekers more apparent, e.g., from Afghanistan, Iraq, Sri Lanka and China (Pieke et al., 2004), but also trafficked persons, unauthorized migrants (who transitvia Eastern Europe) and, morerecently, highlyskilled workers including students and trainees (ICT, health and engineering). In particular, China is of significance for transnational ties and development linkages, now that restrictionsto mobility havebeen lifted, China's economy is booming and is becoming an important partner for business networking.

Up until now, migration has not figured as an important issue in European relations with Asian countries, but this will change given the intensifying migration linkages between the two regions. Dial ogues and programs between Asia and Europe have hitherto been concerned with readmission agreements, countering people smuggling/ trafficking ${ }^{11}$ and

${ }^{11}$ Two Regional Ministerial conferences on people smuggling and trafficking in human beings were held in Bali in 2002/ 2003, where actions plans were initiated. 
refugees assistance. In A sia itself, the discourse has mainly focused on the negative (socio-economic) impacts of temporary labor migration for the countries of origin. Return migration of the less skilled is structural and given.

As to Asia-EU relations, migration and trafficking have been incorporated into the regional and bilateral dialogues with Southeast A sian countries (EC, 2003a:5). In the migration field, the EU prefers bilateral cooperation programs to suit the specific situation of the highly diverse Asian countries (EC, 2004). In theEC strategy paper (EC, 2003a:12) unauthorized migration is considered harmful for development and is targeted for intervention within the framework of an integrated and holistic policy framework:

Moreover, the EC takes a holistic approach to its broadened policy agenda, acknowledging the inter-relationship of different issues and addressing them through integrated policies. Thus, terrorism, organized crime and illegal migration undermine the rule of law, discourage investment, and hinder development. that:

Furthermore, the EU Regional Strategy paper on A sia (EC, 2004) states

Migration takes an increasingly prominent role in the relations between thetwo continents and al so in discussions at official level. Asia is the source of potentially significant - documented and nondocumented - migratory flows to Europe. TheEU and Asian countries have started a dialogue on this common challenge in the context of ASEM $^{12}$ and are beginning to develop common approaches at bilateral level.

However, as of yet, theEC cooperation with ASEAN currently does not clearly and explicitly includemigration and development issues. Similarly, the Hanoi Declaration on Closer A SEM Economic Partnership (Hanoi, 9October 2004), whileaiming at thestrengthening of business, investment opportunities and the trade in goods and services, does not mention migration issues specifically.

Thus, the emphasis in EU-A sian cooperation in thefiel d of migration is still on control of migration flows, readmission of migrants and countering unauthorized migration and trafficking within the framework of mainstreaming Justice and Home Affairs issues (EC, 2003a:39; EC, 2004b). This is done through exchange of information, training of immigration

${ }^{12}$ A sia Europe M eeting 
officials, capacity building and improvement of border control systems. ${ }^{13}$ For theSoutheast A sian region, the program is still tentativeand in a phase of orientation and identification of possible areas of cooperation. The dialogue within ASEM and ASEAN priority is given to -anti-trafficking projects (EC, 20004b).

As to highly skilled and professional migrants, the EU supports the training, mobility and return of scientific personnel and trainees. Within the context of the A sia-Link program, the EU aims to foster the involvement of expatriate scientists with their countries of origin. ${ }^{14}$ In addition, due to the shortage of highly skilled workersin sectors such as ICT and heal th, several European countries have entered into bilateral agreements with Asian countriesfor thesupply of theseworkers. For instance, Germany and theUK have allowed for the immigration of Indian engineers and ICT workers. Next to that there is an increasing demand for unskilled labor in care and domestic services, but this flow, however, is less regulated.

In the next two sections we will focus on the shift in discourses in the Netherlands and Germany, respectively. Comparing the Dutch and German cases is interesting in that it highlights the contrasts in migration experiences and thinking about transnational relations and immigrants' contribution to their countries of origin. Østergaard-Nielsens' (2000; 2001) research, whilefocusing on thepolitical participation of Turkish and Kurdish immigrants, brings out the contrasting institutional and political contexts, i.e., a moreinclusivepolitical system ( $N$ etherlands) againsta moreexclusive system (Germany), and shows how both governments exhibit a sensitivity towards "homeland politics." ${ }^{15}$ M oreover, Østergaard-N ielsen asserts that theN etherlands differswith Germany interms of hosting migrant diasporas that aremoreorganized which support morediaspora-development initiatives.

${ }^{13}$ Concerns Hong Kong, China, Pakistan, India, Sri Lanka.

${ }^{14}$ Theobjective of the A sia-Link Program is to promoteregional and multilateral networking between higher education institutions in Europe, South and Southeast A sia and China. Eligible countries are the $25 \mathrm{Member}$ States of the European Union and 19 A sian countries.

${ }^{15}$ A ccording to Østergaard-Nielsens (2001), in the Netherlands, given its more inclusive multicultural policies, there is a tendency among policymakers to view the taking part in "homeland" politics by Turkish immigrants as a failure of immigrant incorporation and integration policy. 


\section{Dutch D iscourses and Policies}

In the case of the Netherlands, five periods characterized by a specific economic conjuncture, type of immigration and subsequent discourse on migration and development, can bedistinguished:

1. The first wave of non-European immigration in the Netherlands occurred shortly after World War II when 10,000 Indonesian-Dutch (mestizos of the Dutch Indies) and M oluccan soldiers in the service of the colonial army, left Indonesia. During the period of their arrival, from 1945 till about 1960 , the Dutch economy and society underwent substantial changes. The foundations were laid for a post-colonial industrial and welfare state. The reconstruction went together with a tight labor market, and full employment facilitated the integration of the immigrants. The predicament of developing countries was not really on the agenda, hence, there was no debate on migration and its link with development.

2. During thenext period, 1960-1973, likein other parts of N orthwestern Europe, sustained economic growth continued and shortages in the labor market led to the recruitment of foreign 'guest workers,' mainly from M orocco and Turkey. This period ended with theso-called oil-crisisand the coming to a standstill of theguest worker program. Thefirst debates on the relation between migration and development took place in this period, focusing on the underlying reasons for migration (poverty) and "highlyskilled migration.' The latter, in particular, became part of 'developmentalism' (balanced growth) and 'dependency' (asymmetrical growth) discourses and was consequently framed in terms of -'brain gain' or 'brain drain.'

3. 1973-1990 was a period of recession and restructuring of the Dutch economy that gradually evolved from a Fordist to a post-modern, serviceoriented and knowledge-based economy. Economi c growth stagnated and unemployment became widespread. Contrary to original expectations, many guest workers stayed in the N etherlands, their families came over under family reunification arrangements, and a largepart of them obtained Dutch nationality. Return migration became part of the migration and development debate. In 1973 the Directorate-General for Development Cooperation (DGIS) started a re-migration program called Reintegration of EmigrantManpower and Local Opportunitiesfor Development(REM PLOD) that lasted sixyears. Studieswerecarried out to evaluatetheresults and they showed that although re-migration could be successful at the individual level, at the village level sustainable positive effects remained to be seen (A badan-Unat, 1975).

4. In the period 1990-2000 the West European economy recovered and the labor market improved. Intensified globalization and political repres- 
sion and civil wars in the former Yugoslavia, Iraq, Iran, A fghanistan and Somalia caused an increase in the number of asylum seekers and refugees. The Netherlands was one of the countries that received this wave of immigration. Migrants' origins becamemorediverse. With 15 percent of its 16-million population born outsidethecountry or having at leastoneparent born outside the country, ${ }^{16}$ Dutch society gradually became conscious of being an immigration country. Resistance against immigrants, especially asylum seekers, increased.

It is against this background that a new discourse - the causes of migration/ brain drain and return migration- appeared. Thefirstissuewas taken up mostly at thetheoretical level (e.g., seeH eins and Kox, 1998) while thelatter wastranslated in policies. Successi vegovernments spent millions to promote the return of asylum seekers and migrants to the countries of origin. Threere-migration programs werelaunched, none of them successful. ${ }^{17}$ To these discourses a third discourse was added focusing on transnationalism and the role of migrant communities or diasporas. After 1990, the role of diasporas in development projects increasingly received more attention, not the least because of the efforts of migrant organizations. ${ }^{18}$

5. The current period, from 2000 till the present, is characterized by economic recession, an increase in the level of unemployment, and immigration as a core issue in Dutch politics. Like in other European countries, theDutch asylum policy hasbecomemoreand morerestrictive, intensifying thediscourse of return migration and development in theprocess. On A pril 1,2000 the Law on Re-migration became effective. It aims at facilitating the return of accepted asylum seekers and migrants who want to return volun-

\footnotetext{
${ }^{16}$ Regarding the Dutch definition of the 'allochtonous' population, allochtones should not beseen as synonymous with foreigners since many of them had Dutch nationality when they migrated from theformer colonies; many othersobtained Dutch nationality. Thelargestgroups are those of Dutch-Indonesian $(450,000)$, Surinamese $(325,000)$, Turkish $(350,000)$ and Moroccan $(250,000)$ descent. N ew large immigrant groups are from A fghanistan, Iraq, Iran, China, Ghana and Somalia.

${ }_{17}$ These programs are: 1) Return and Emigration of Asylum Seekers ex Netherlands (REA N), under which program 6,700 people returned between January 1992 and May 1998; 2) Facilitated Return of non-A ccepted A sylum Seekers (GTAA), which assisted the return of 900 asylum seekers from Ethiopia and 300 from Angola; at the beginning of 2000 only 13 asylum seekers had returned; and 3) Facilitated Return to Somalia- no one returned under this program.
}

${ }^{18}$ Examples are the Euro-M editerranean Center of Migration and Development (http:/ / www.emcemo.nl/ ), and a conference organized by the National Consultation of Municipalities and Development (LOGO), where organizations of migrant communities and Dutch development organizations discussed opportunities for cooperation (Posthumus, 1996). 
tarily to their home countries. The Netherlands Migration Institute, on behalf of the Ministry of Internal Affairs, implements the Law, which provides transport costs and financial assistancefor thefirst two months. In addition to thelaw, political developments in I raq and A fghanistan invited return migration and development projects in these countries. The Dutch European Refugees Fund (N ederlandse Europees V luchtelingen Fonds), for example, al located morethan onemillion eurosfor return migration in 2003.

What is new is theinvolvement of development funding agencies such as Cordaid, Interchurch Organization for Devel opment Cooperation (ICCO), N etherlands Organization for International Development Cooperation or NOVIB (Oxfam N etherlands). For example, Cordaid started an organization (Bureau M aatwerk voor Terugkeer' $=0$ fficefor Tailor $M$ adeR eturn), with the aim to mediate between rejected asylum seekers and the demand of development organizations in countries of origin. However, their efforts haveyet not proven to beeffective, among others because: "It is characteristic of the projects that they target peoplewho havebeen for years involved in asylum procedures, who are not accepted and who receive welfare without much perspective for work. Seldom had the discussion focused on the return of people who bel ong to the better-off of the refugee population" (Kalsbeek, 2003:3). N evertheless, it is significant that migration is now on the agenda of development NGOs.

The discourse on migration and development received a new impetus with the publication of a policy paper 'Development and Migration,' written on behalf of both the Minister of Development Cooperation and the Minister for Foreign Affairsand Integration. Thepaper aimsat bringing into balancepolicies of poverty alleviation, conflictmanagement and protection of human rights with theelasticity ('span kracht') of Dutch society regarding legal and undocumented immigration and multiculturalism. In fact, the reportbringsthethreediscourses discussed earlier together. A new element is the framing of the migration and development issue by paying attention to national and regional contexts. Thecentral issueatstakeiswhy migration generates more positive effects in some countries compared to other countries.

The report focuses on two areas: remittances and human capacity building. Remittances are considered beneficial to countries with a favorable climate for entrepreneurs: "There are indications that in particular in countries with a favorableclimatefor entrepreneurial activities remittances will indeed lead to extra investments and, in situations with sufficient surplusproduction capacity, to substantial economicgrowth. Thereareal so strong indications that the poor (al though not the ultra poor) will benefit from the remittances" (Royal Dutch Government, 2004:34). Human capacity building is related to theroleof diasporas, which is supposed to generate 
traderelations, international capital transfers for investments and transfer of technology. The general conclusion of the policy paper is that the effects of international migration are positive for the middle income countries because of economic opportunities to invest. The relation between international migration and lower income countries is less clear. Of decisive importance is the development environment: political stability, economic growth, thequality of government, policy and business climateand whether the emigrants are high or low skilled.

Based on this analysis, a new policy was devised. Among others, the policy paper states that the government will involvemigrant organizations moreintensi vely in thedesign of Dutch developmentcooperation and in the debateon brain drain. Moreover, efforts of migrantorganizationsto contribute to development in the countries of origin will be supported. It further considers the promotion of circular migration as a suitable strategy that unifies theinterests of themigrants, the countries of origin and the destination countries. Theseconclusions imply that governmental policy acknowledges that the transnational linkages of migrant organizations contain a potential for economic and political development in thehomecountries. In the following paragraphs we will give some examples with regard to diaspora organizations formed by migrants of Indonesian origin.

There are many local organizations and activities in the Netherlands that support small-scal e projects in Indonesia. The M oluccans who cameto theN etherlands around 1950 numbered about 42,000 as of 2001(Beets etal., 2002). They originally assumed that their stay would betemporary and that they would return to a free Moluccan republic. This ideal and the adat (traditional law) and pela (kinship) linkages still play a role in constituting the Moluccans as a migrant group with a clear, well-defined identity. Kinship relations areal so important in keeping thelinks with the M oluccan Islands in East Indonesia. In 1999-2001 violentethnicand religious conflicts occurred in theregion of origin, during which at least 5,000 peopledied and 500,000 were displaced. The Moluccans in the Netherlands undertook various initiatives and demonstrations to express their solidarity; thelatter werejoint efforts by Christian and Muslim Moluccans. Political pressureto end the violence was exerted, both on politicians in the N etherlands and in Indonesia, and twice a delegation of prominent members of the diaspora visited political leaders in Indonesia. The diaspora also became much involved in relief efforts. Campaigns were held to collect money, at the national level by way of a national aid campaign supported by two Dutch mayors and the Dutch Red Cross, as well as by numerous local actions. The national campaign resulted in 5.5 million Dutch guilders (around 2.75 million euros) in 2001. Steijlen (2004) suggests that theinterethnic conflict of 1999-2002 has strengthened transnational ties, and the emergency assistance developed into development oriented small-scale projects. 
Thesecond group is smaller and consists of Papuans from West Papua (Irian Barat) that was separated by the Dutch from the rest of Indonesia during thetransfer of sovereignty in 1949. Given their small number, there areonly afew diaspora organizations of Papuans. Thecoremembers consist of Papuans but their membership includes Dutch sympathizers. Hulp aan Papua's in N ood (HAPIN), which standsfor 'Support to Papuansin distress,' is a case in point. It claims to have 12,000 member-contributors. It combats human rights abuses by thearmy and supports theregional autonomy and decentralization laws of Indonesia that should lead to greater inclusion of Papuans in regional decision making. HAPIN also has various project activities, such as support to four boarding schools, emergency aid, information, and support to refugees in Papua N ew Guinea. In 2003/ 04 grants were given to 450 students for higher education both in West Irian and elsewhere in Indonesia. Besides, a small fund supports initiatives of local populations in the field of small scale production and education. ${ }^{19}$

The above examples demonstrate how the relations between migrant groups and their countries of origin could beinter-generational and maintained for decades. They also show the current interest in mobilizing the resources of migrant organizations for development. This interest is not only from thesideof Dutch privateor semi-governmental fundingagencies, but also from the Dutch government. An example of an Asian initiative supported by the Dutch government is a project of the Dutch-Filipino organization PASALI, an organization of Filipino seafarers. It initiated a project "from brain drain to brain gain," with theaim to usetheknowledge and skills of expatriate Filipinos to develop the fishery and agricultural sector; to foster the economic and social reintegration of returnees and to help avoid the migration of Filipino graduates (IOM, 2004c).

The discourse on transnationalism and development is, of course, not only a matter for policymakers; it is also a matter of academic interest. Gradually, more academic work has been done on the subject and three Dutch studieswill behighlighted herethat show differentresults. Thestudy of JanineKlaver (1997) on labor migration from Oaxaca (M exico) to theUSA is one of the first Dutch studies on transnationalism, based on fiel dwork in two villages in the Oaxaca region and the diaspora community in Los Angeles. It pays much attention to cross-border social networks. Labor migration is a major livelihood strategy for many Oaxaqueños, but, accord-

19 Since 2002, this fund is supported by the Dutch funding organization NOVIB (Oxfam Netherlands), which allowed for expanding assistance programs. The LINKIS/ NOVIB Program is meant for co-financing of small scale development projects of Dutch civil society organizations, including migrant and refugee organizations (see www.linkis.nl). 
ing to the researcher, on balance the effects of migration on the social and economic development are negative, both at household and village level. Adverseeffectsarethelack of adultmalesin thevillages (although moreand more young women migrate); the neglect of investments to increase production; and theincreasein fallow land and thedecreaseof land cultivation. Whileincoming remittances increasethestandard of living, it leads to everhigher expectations and ambitions. While migrants support individuals and migrantorganizationssupportpublicworksinthevillages of origin, the idea of solidarity and mutual assistance weakens in due time.

A study in Indonesia (Spaan, 1999) showed that labor migration (either internal or international) was part of strategies adopted by households across all socio-economic strata in the study sites to diversify the households' resource base. International labor migration was more prominent in communities with a high degree of development and economic incorporation in the wider economy. The poor and landless managed to cover the initial costs of migration by taking loans and using the services offered by intermediaries (as against paying placement fees to recruitment agencies). The investment patterns of migrants varied by socio-economic stratum: poorer migrant households tended to use earnings for housing, livestock and repaying debts, while more well-endowed migrant households invested more in productive assets such as land, transportation, tools or accumulated savings. In some areas, the local government benefited by appropriatingapercentage of migrantremittancesfor infrastructureprojects. The high brokerage fees and ensuing debts, however, prevented many migrantsfrom making productiveinvestments. Theseintermediaries, often return migrants, were important investors and served as catalysts of local economic devel opment (Spaan and Hartveld, 2002).

The third study by Hein de Haas (2003) analyzes migration and development in an agricultural area in southern Morocco. For more than three decades cross-border migration to Western Europe is part of households' coping strategies. Many of the migrants obtained a permanent permit to stay, others returned while there are al so circular migrants as well as legal and undocumented migrants. A ccording to IMF data, remittances to Morocco totaled US $\$ 3.3$ billion in 2001 (Nyberg Sorensen, 2004:5). In his study area, DeH aas estimatestheannual value of remittances atsome12.2 million euros. This is spent on the improvement of agriculture by buying water pumps, fertilizers, agricultural machines; housing; education; the Muslim pilgrimage to Mecca; purchase of luxury consumption goods, etc. In addition, diaspora organizations support communities by supporting hospitals and building new mosques. De Haas shows that there is more prosperity than before, that traditional cleavages the between traditionally powerful and marginal groups are eroded, and that women are more educated than 
before. On the other hand, he admits that the poorest families are not (able to be) involved in the migration culture and that there is an increasing agrarian inequality. De Haas' study exceeds narrow interpretations of 'development' as purely an economic process.

In summary, the different findings of these studies support the thesis that the context determines the outcome of transnational linkages. Besides, the three studies together mark the transition in the Dutch migration and development debate from a rather skeptical and pessimistic point of view towards a more positive and optimistic one.

\section{The G erman D iscourse on Migration and Development}

Also in the case of Germany it is helpful to distinguish periods marked by specific economic and political characteristics, type of immigration and subsequent discourses on migration and development. Germany's immigration history is marked by a paradox. In post-war Europe Germany becameone of themost prominent immigrant countries- even if therewas no declared policy towards immigration and integration. But it was only in 1998, 43 years after thefirst recruited migrant laborers came, that Germany declared itself officially to bean immigration country. From theoutset, the access of migrants to the labor market was highly regulated, and the regulations were contradictory (Bade, 2001).

1. A fter the collapse of the Nazi-regime with its anti-Semitic and racist policies towards migration and its extensive use of forced labor, Germany was confronted with remarkable streams of refugees. Most refugees came from the Eastern territories and fled to Western Germany. Internal migration was directed nearly exclusively towards Western Germany as well. Thisfirst phase of migration ended in 1961 when theBerlin Wall was raised and internal migration between the two German states was blocked. Western Germany started to prosper economically as a result of the Marshall Plan, but it was short of labor. Recruiting from the refugee population and other solutions (such as increasing the participation of women in thelabor market) were not on the political agenda.

2. Theimport of migrant labor turned out to bea reasonablesolution to thelabor shortagefor theeconomic and political actors in this period. From the outset the recruitment of workers was directed towards European countries and potential immigrants coming from Asia or Africa were excluded. In principle, it was less a preference for 'Europeans' but the exclusion of individualswho, in internal parlance, werefrequently referred to as 'A fro-A sians' (Schönwälder, 2004:249). Therecruitment of thousands of workers, mainly from Southern European regions took, place from 1955 onwards and was managed by a loose coalition of big enterprises in the 
booming industries and the German government. It was not accompanied by an integration policy for the immigrants. Contracts for the recruited workers were made originally on a one-year basis. The main countries of recruitment at the timewereltaly, Greece, Turkey, Spain, Portugal and the former Yugoslavia. Initially, countries like Bolivia, Taiwan, India, Iran, Togo, the West Indies and the Central African Federation had offered to send workers to West Germany. However, Germany rejected those offers; later it accepted workers from Morocco and Tunisia. The recruitment treaties did not contain provisions on the immigration of family members of the recruited workers. This made it difficult for immigrants from developing countries to bring their families to Germany. In 1973 the German government stopped its recruitment policies due to the oil crisis and economic recession (Rist, 1980). ${ }^{20}$

3. Since 1973, thethird phase of migration to West Germany continued through threemodes: special agreements covering the recruitment of (seasonal) workers; the repatriation of so-called ethnic Germans from Eastern Europe (people having German descent), and asylum and refugee migration. Thesemigrations wereregulated directly (e.g., visa requirements) and indirectly (e.g., the treatment of spouses and children who were admitted under family reunification). Many of the immigrants stemming from the guest worker system brought their families to Germany, indicating a consolidation of this immigrant generation (Bade, 2001).

In addition, Germany forged special agreements with several countries for thebenefit of certain sectors that need ed qualified workers. In the1970s and 1980s there was already a limited inflow of Korean and Philippine nurses to Western Germany. Those two immigration groups were largely female; unliketheguest worker program, therewas no possibility for them to bring their spouses and children to Germany ${ }^{21}$ In the late 1970s refugees from Vietnam (known as the 'boat people') were al so allowed to come to Western Germany. They received institutional support and, compared to other refugee groups, they integrated rather quickly into the Western German society.

In this phasetheidea that poor countriesshould not bedeprived of their well-educated personnel dominated the debateon therecruitment of workers from developing countries. Left-liberals criticized the recruitment of

${ }^{20}$ In that year 72,946 A frican and A sian citizens, representing 3.11 percent of the foreign workforce, weregainfully employed in Germany. Thetotal number of foreigners in Germany was about four million persons (Schönwälder, 2004:254).

${ }^{21}$ Most of the South Koreans al ready cameto Germany in the 1960s and 1970s as nurses or miners. Filipino migrants had lived in Germany for many years and often work as nurses (women) or as seafarers (men) (see Schmidt-Fink, 2004). 
nurses from South Korea since it also had a shortage of medical personnel (Schönwälder, 2004:258). The brain drain debate was high on the agenda and the concept of brain drain itself became a highly politicized issue (see Schipulle, 1976:193). Germany's repatriation policies focused on the guest worker population. A program launched in 1983 offered incentives for return migrants to Southern Europe. It did not meet the expectations of the government and it ceased within a few years (Entenmann, 2002).

East Germany (German Democratic Republicor GDR) foll owed its own recruitment strategies. The GDR recruited workers (so called W erkvertragsarbeiter) from a variety of social ist developing countries in the 1980s and 1990s, mostly from Cuba, Mozambique and Vietnam. In this case the migration policies did not invitethepermanentstay of migrantsin theGDR. The immigrants lived in segregated condominiums and had little contact with the country of destination. The most numerous group of immigrants weretheVietnamese. They wereableto maintain astrong relationship with their country of origin and they sent all kinds of goods to their country on a regular basis (Hillmann, 2005).

4. After reunification in October 1990 many immigrants living in the former GDR were not captured by an appropriate legal framework and, subsequently, became a main target of repatriation policies. Statistics suggest that about 19,500 out of 60,000 V ietnamese left the country for good in the years after reunification. A rbeitsgruppe Entwicklung und Fachkräfte im Bereich der M igration und Zusammenarbeit (AGEF), an official mediator for migrant reintegration in Vietnam, estimates that nation-wide about 12,000 Vietnamesewent back to their home country in the 1990s (Hillmann, 2005). While Germany wanted the former contract workers to return home, Vietnam itself was not keen to havethose migrants back because of its own economic problems.

Up until today the immigrant population in Germany, though highly diverse, isstill mainly "European," exceptin theeastern parts of thecountry. In theyear 2002about 12 per centof all foreignerscamefromAsia(Statistisches Bundesamt, 2002). Asian immigrants are a diverse group; they came to Germany in various ways. It may berecalled that theFilipinos and Koreans were part of specific recruitment agreements; as detailed below, all other groups did too under certain labor market regulations. Today, a substantial proportion of the immigrant population lives under uncertain conditions, as asylum seekers or as "tolerated immigrants" who do not have theright to work in Germany. Among Vietnamese, Afghan and Sri Lankan immigrants, lessthan afourth held an unlimited permittostay in 2002 (Beauftragte der Bundesregierung, 2003). In addition, thereare migrants withoutalegal status; they work in theinformal sector of theeconomy (Schönwäl der, Vogel and Sciortino, 2004). Furthermore, possibilities for self-employment were 
for many years restricted due to complex bureaucratic procedures. Students from developing countries areallowed to stay in Germany, but only since January 2005 , when thenew law on immigration was passed allowing them to stay for another year to find work in the labor market.

Thebiggestimmigrantgroup from A sia, theVietnamese, isnow mainly engaged in self-employment. Thesecond group, theChinese, camemainly asspecialty cookssincethe 1960 s. M orerecentarrival scamemainly to study at German universities. In 2003, 9,109 Chinese were registered as students at German universities. It isestimated that many Chineseimmigrantstoday stay illegally in Germany and that this kind of immigration is on the rise (Giese, 2003). Immigrants from Thailand include women who had been trafficked (IOM, 2003b). Large numbers of Thai women also came in the context of marriage migration. Data indicate that in the year 2002 2,775 marriages were registered between Thai women and German men, while marriages between Thai men and German women are exceptional. ${ }^{22}$

In 2000 theso-called "Green card" program was introduced to bring in about 20,000 highly special ized IT-workers to Germany. In 2003 half of the 13,774 recruited IT- workers camefrom India. The "Green Card" program marked the beginning of a new era of immigration policies in Germany because it implied that Germany should make more use of its integration into global labor markets.

\section{Policies of Return and Repatriation}

Asthis brief review of Germany'simmigration context shows, theaccess of immigrants to the country and to the labor market was highly regulated from the outset. As in the case of the Netherlands, Germany also implemented repatriation policies. Limited data on the dimensions of voluntary repatriation are available and there is no central coordination of actions in this respect; an evaluation of repatriation programs is al so lacking (M oritz, 2005; Entenmann, 2002). Several institutions are involved at various levels and there is a growing consensus among policy makers that return programs should be given more attention than was the case in the past (Unabhängige Kommission Zuwanderung, 2001).

Incooperation with the International Organization for Migration (IOM), Germany came up with the program, "Remigration and Emigration for Asylum seekers in Germany" (REAG), in 1979. The program aimed at

22 In comparison 26 marriages between a German woman and a Thai man were registered in 2002 (Beauftragte der Bundesregierung für Migration und Integration, 2004). 
assisting migrants and refugees willing to return to their countries of origin. Theprogram provided travel subsidiesand reintegration assistancethrough income-subsidies in the country of arrival under the Government Assisted Repatriation Program (GARP). In the years 1979 to 2003 a total of 543,052 migrants availed of the program (IOM, 2005b:153). At the national level, return programs involvethreeagencies: the Ministry of Labor, specifically the Zentralstelle für A rbeitsvermittlung (ZAV) unit, which takes care of migrants who have studied in Germany and who want to return to their countries of origin; the Ministry of Internal Affairs (BMI), and the Ministry for Development (BMZ), which run special programsto facilitatethereturn of migrants and refugees..$^{23}$

At the local community level some authorities offer economic help to migrants willing to go back to their countries of origin (Entenmann, 2002). Mediatory agencies as well as church organizations are also involved in carrying out repatriation programs. Generally three forms of return programs exist: (1) financial and organizational help for the trip back home, including financial support during theinitial stagein thecountry of return, (2) programs for the economic reintegration of employees in the form of training and job exchange, and (3) financial support, access to credit and consultancy services in setting up a business. Large-scale programs are directed towards certain groups of migrants, for exampleBosnian refugees, while small-scale programs are more tailored to individuals. Recently a special unit, ZIRF (Zentralstelle für Informationsvermittlung zur Rückkehrförderung), has been created to coordinate and organize the return programs and to enable potential returnees better to do so (M oritz, 2005).

\section{The Shift in the Discourse: Empirical Evidence}

Even if Germany did not favor the settlement of migrants from developing countries (and had, in fact, recently created ZIRF, an institutional body to better coordinate the return of migrants back to their home-country), the debateon migration and development surfaced in Germany in the past two to three years. The policy of the 1970s and 1980s viewed the emigration of highly qualified migrants from the developing countries, labeled as 'brain drain,' as detrimental to the development of the countries of origin. This argument justified the practice of sending students from devel oping coun-

\footnotetext{
${ }^{23}$ Germany has agreements on repatriation with several other countries such as A Igeria, Bosnia Herzegovina, Bulgaria, Croatia, Morocco, Poland, Romania, the Czech Republic and the Baltic states (Sachverständigenrat, 2004).
} 
tries back home once they obtained a university degree in Germany. Generally the discourse on migration and development has shifted away from thestigmatized brain drain debate, and now underlines aspects of the brain gain (see Hunger, 2003).

In this changed debate the focus now is on the more positive effects of return migration for thecountries of origin. Migration, it isargued, becomes a tool for development and transnational networksmight lead to a win-win situation in the country of arrival and in the country of origin. This line of thinking challenges the notion that improved development strategies for thedeveloping countries could prevent migration from poorer countries to the rich countries (Thränhardt, 2005).

This shift in the discourse is due to two major trends: (1) a new, more transnational understanding of 'development' within globalization processes, which includes theinfluence of international policy-oriented NGOs in the field of migration studies; and (2) changed local realities in Germany itself.

Asregardsthefirst trend, proponents of thediscourseon migration and development in Germany areoriented toward theAnglo-Saxon discoursethey compare the situation of migrants in Germany with that of the UK or the US, even if the level of organization of the immigrant communities as well as the status and the possibilities for integration differ among the various countries. Often reference is made to the economically successful examples of global diasporas like the Indians and Chinese. The guanxi model of the overseas Chinese community is seen as a viable resource for many migrantsall over theglobe. Melchers etal. (2004) blamethemigration experts in Germany in putting too much attention to the 'negative' aspects of immigration to Germany while failing to pay sufficient attention to transnational forms of migration, including diasporas. Some of the more policy-oriented scholarsnow call for a better integration of the diasporainto development policies (Kuptsch and M artin, 2004; Süßmuth, 2004). A sin the Anglo-Saxon discourse, diasporasin Germany arenow examined moreand moreas a potential tool for poverty-reduction in thecountries of origin. The 'Anglo-Saxon conception that "individual s constitute themost sizableand tangibleform of diaspora contribution to development and poverty reduction" (Van Hear et al., 2004:3) goesalong with a changing view of migration. Today the diaspora is seen as a provider of remittances and knowledge for the developing countries. A better management of those remittances might stimulatedevelopment at home. Someauthors view Germany as not doing much to recognizethepositivevalue of its diasporacommunities(Melchers et al., 2003).

The second trend concerns changes in German society. The demographic trend shows a decline in fertility rates and the greying of the 
"native" population. According to some experts, falling birth rates and the anticipated problems of a shrinking society could bemitigated by immigration from abroad (Thränhardt, 2005). As mentioned earlier, Germany has already allowed the access of highly-qualified workers to the IT- sector, systemically recruiting workersfrom developing countries such as Indiafor this economic purpose.

Few scholars are aware that many assumptions about diasporas in Germany are based on limited knowledge of the nature and dynamics of immigrant groups (Mundt, 2004). Theavai lablescientific evidenceis much more critical in tonethan the briefly sketched debate here suggests. While anecdotal evidence seems to highlight the success stories, more solid research shows that the impact of the returns at the local level in the country of origin arelikely to beoverestimated (for the M oroccan case, see Berriane, 2001) or that migrant groups would need other preconditions to invest in their home countries. A study on the voluntary repatriation program of Afghan refugees underlines the loose connection of migrants within the diasporaand the difficulties of migrantsin thecountry of destination and in the country of origin (Schmidt, 2003). Research on Bangladeshi migrants in Germany shows that most Bangladeshi cameas refugees and that only onethird of them send home remittances on a regular basis (Feuchte, 2002). Ongoing research on the Ghanaian community in Germany indicates that the ties between the diaspora and the home country exist, but these are mostly based on an individual, non-organized fashion. While remittances aresentback home, oftentimesthisisnoton a regular basis. Highly qualified migrants stated that there was no need for them to send remittances home since their families were well established there.

On the whole, the link between migration and development turns out to be mixed: remittances are sent, but as empirical evidence suggests, these are sent mostly in order to pay school bills and used for consumption or to offer help in needy situations. Some of those who had tried to establish developmentprojectsathome(e.g., sending medical-technical instruments), turned out to be frustrated by the bureaucracy at home (e.g., high import taxes) and cases of donated instruments being stolen. Similar skepticism is indicated by astudy on mi grants who cameto study in Germany and stayed thereafter. Most of them have a strong emotional bond to their country of origin, butvery few havethefinancial freedom to visittheir country of origin every year (Schmelz, 2004). A study on theintegration of refugeewomen in theregion of Berlin and Brandenburg indicates further that many migrants from developing countries remain isolated in the county of arrival and that their integration into thelabor market is difficult, given theconstraints they face, and thus their economic resources are also limited (Foda and Kadur, 2004). 


\section{Conclusion}

Astheoverview attests, the debateon theadvantages and disadvantages of migration for the development process has not been conclusive. The debate has long focused on issues such as remittance flows and brain drain, but recently changed focus to issues such as brain circulation, transnational migrant entrepreneurship, and diasporalinkages with local politics, societiesand economiesin countries of origin. Thespecificimpacts of bilateral and multilateral policies on these latter issues are hard to gauge since they are recently initiated and still being debated. Furthermore, there seems to be some association between the discourses and policies relating to immigration (control) and local developmentthrough return migration and diaspora involvement.

The involvement of migrant diasporas in developments in their countries of origin is not something new; all kinds of diaspora initiatives for development and reconstruction efforts have been going on for a long time. Civil society and governmental involvement in this field is generally independent. Recently, therearemoreattempts by governments to involveand support return migrantsand diaspora organizationsin transnational development polices and efforts. This is the case in France and the N etherlands; at theEU level, awareness of this issuehas grown.

In this respect, the Dutch case- which hasastrong minority population coming from developing countries - shows some optimism and the sense that therearenew opportunities for positiveoutcomes in linking migration with development issues. In the German case, existing as well as ongoing research on the relationship between migration and development point to a mixed picture. In Germany, the available data on the numbers of immigrants from developing, especially Asian countries, does not at first sight underline the thesis of strong diasporas that could shape a more effective development policy vis-à-vis thehomecountries. The potential of migrant diasporas has not yet been recognized as such. Herea careful reading of the Anglo-Saxon discourse would be appropriate.

Given thestill underdeveloped policies linking international migration and development, weunderscoretheconclusion madeby Nyberg-Sorensen etal. (2002) that theroleof migrants as development agents should get more weight in discourses and policies. This paper shows that there are differences in national frameworks whereconcrete policiestake place- and that the discourse is moving beyond the scope of repatriation. However, there still tendsto bean emphasis on economic aspects, whilethesocial costsand internal fragmentation in the countries of origin resulting from international migration and transnationalism receive less attention. Finally, it should be acknowledged that up to now knowledge about immigrant 
groups is limited and often gl osses over thetransnational aspects of migration. In other words, more definiteconclusionsregarding theroleof diasporas in development have to be postponed.

\section{REFERENCES}

A badan-Unat, Nermin

1975 M igration and D evelopment. A Study of the Effects of International Labor M igration on Bogazliyan District, Turkey. Ankara: Ajans Turk Press.

Ammassari, Savina

2004 "From Nation-building to Entrepreneurship: The Impact of Elite Return Migrants in Côte d'Ivoire and Ghana," Population, Place and Space, 10(2):133-154.

Amuedo-Dorantes, Catalina and Susan Pozo

2003 "Workers' Remittances and Business Ownership in the Dominican Republic." Research Papers, Department of Economics, Western Michigan University. http:/ / homepages.wmich.edu/ Pozo/ research\%20papers/ business_september_2003.pdf, accessed on 18 A pril 2005.

Arbeitsgruppe für Entwicklung und Fachkräfte (AGEF).

2004 Reintegration A pproaches and Policies on EU level- A nalysis and Recommendations. Final Report. Berlin: Arbeitsgruppefür Entwicklung und Fachkräfte(AGEF). Also available at http:/ / www.reintegration.net/ europa/ reintegration_net_final_report.pdf.

Aumüller, Jutta

2004a “Migration and Development Aid Policy. Practical Models of Implementation." In M igration and Political Intervention. Theories and Debates, Vol. 1. Edited by Jochen Blaschke. Berlin: Europäisches Migrationszentrum (EMZ).

2004b “Migration Control through Co-développement." In M igration and Political Intervention. Theories and Debates, Vol. 1.Edited by Jochen Blaschke. Berlin: Europäisches Migrationszentrum (EMZ).

Bade, Klaus, J.

2001 "Ausländer- und Asylpolitik in der Bundesrepublik Deutschland: Grundprobleme und Entwicklungslinien." In Digitale Bibliothek, Friedrich Ebert Stiftung. http:/ / library.fes.de, accessed on 28 A pril 2005.

Beauftragte der Bundesregierung für Migration, Flüchtlinge und Integration (BBMFI)

2004 D aten - Fakten - Trends. Strukturdaten der ausländischen Bevölkerung. Berlin: BBMFI.

2003 D aten - Fakten - Trends. Strukturdaten der ausländischen Bevölkerung. Berlin: BBMFI. 
Beets, Gijs, Evelien Walhout and Santo Koesoebjono

2002 "Demografische ontwikkeling van de Molukse bevolkingsgroep in Nederland," $M$ aandstatistiek van de Bevolking, 6:13-17.

Berriane, Mohamed

2001 "Arbeitsmigration aus N ordafrika und ihre Auswirkung auf die Herkunftsgebiete," Geographische Rundschau, 53(6):38 - 42.

Binford, Leigh

2003 "Migrant Remittances and (Under)Development in M exico," Critique of A nthropology, 23(3):305-336.

Black, Richard et al.

2004 U nderstanding V oluntary R eturn. Sussex Center for Migration Research, United Kingdom, HomeOfficeOnlineReport50/ 04. http:/ / www.homeoffice.gov.uk/ rds/ pdfs04/ rdsolr5004.pdf, accessed on 21 March 2005.

Carlak, Burhan

2004 “Netwerken ontwikkelingshulp gaan samenwerken," Contrast, 10(24):6.

Cheran, Rudhramoorthy

2003 "Diaspora Circulation and Transnationalism as Agents for Change in Post-Conflict Zones of Sri Lanka." Policy paper, Department of Sociology and Centre for Refugee Studies, York University, Toronto, Canada.

European Commission (EC)

2005 "European Union Development Policy Issues Paper," European Commission, DG Development, Strasbourg (7-1-2005), http:/ / europa.eu.int/ comm/ development/ body/ theme/ consultation/ doc/Issues_Paper_EN.pdf, accessed on 18 A pril 2005.

2004a "StrategyPaper and Indicative Program for Multi-Country Programs in Asia 20052006," Commission of the European Communities, External Relations Directorate, General DirectorateAsia, Strasbourg. http:/ / europa.eu.int/ comm/ external_relations/ asia/ rsp/ rsp_asia.pdf, accessed on 21 March 2005.

2004b Regulation No 491/2004 of the European Parliament and of the Council of $10 \mathrm{March}$ 2004 establishing a programmefor financial and technical assistanceto third countries in the areas of migration and asylum (AENEAS), 0 fficial Journal of the European U nion, 18.3.2004, L 80/ 1.

2004c EC Council Conclusions, COM 14292/ 1/ 04 REV 1 CONCL 3, Brussels, December 8. http:/ / ue.eu.int/ uedocs/ cmsU pload/ 14292-r1.en04.pdf, accessed on 20 M arch 2004.

2003a Communication from the Commission on 'A new Partnership with South EastA sia', 9 July 2003, COM (2003) 399 final. http:/ / europa.eu.int/ comm/ external_relations/ asia/ doc/ com03_sea.pdf, accessed on 21 March 2005. 
2003b Communication from the Commission to the Council and the European Parliament: Integrating Migration Issues in theEuropean Union's Relationswith Third Countries, Council of the European Union, Brussels, 5 May 2003, 8927/ 03.

2002 Commission of the European Communities: Integrating Migration Issues in the European Union's Relations With Third Countries Brussels, 3.12.2002, COM (2002) 703 final.http:/ / europa.eu.int/ comm/ external_relations/ news/ ip02_1793.htm, accessed on 7June 2005.

Entenmann, Tina

2002 Reintegration in D eutschland - PolitischeEntscheidungsträger, A kteure, Programme, AGEF GmbH, Berlin. http:/ / www.reintegration.net/ deutschland/ , accessed on 21March 2005.

Feuchte, Beate

2002 "Migration aus Entwicklungsländern in Industrieländer - Bangladesh-Deutschland als Beispiel." MA thesis, Institut für GeographischeWissenschaften, Berlin.

Foda, Fadia and Monika Kadur

2004 Flüchtlingsfrauen-VerborgeneRessourcen. StudiezumForschungsprojektProl ntegra." Deutsches Institut für Menschenrechte, Berlin. Mimeo.

Giese, Karsten

2003 "N ew Chinese Migration to Germany: Historical Consistencies and N ew Patterns of Diversification within a Globalized Migration Regime," International M igration, 41(3): 155-183.

Griffin, Keith

1976 "On the Emigration of the Peasantry," W orld D evelopment, 4(5):353-361.

Guarnizo, LuisE.

2003 “The Economics of Transnational Living," International M igration Review , 28(3):666699.

Haas, Hein de

2003 "Migration and Development in Southern Morocco. The Disparate Socio-economic Impacts of Out-migration on the Todgha Oasis Valley." Ph. D. diss., University of Nijmegen.

Hanoi Declaration on Closer Asem Economic Partnership

2004 http:/ / europa.eu.int/ comm/ external_relations/ asem/ asem_summits/ asem5/ index_sum_cond.htm, accessed on 21 March 2005.

Heins, J. and H. Kox

1998 M ensen op drift. M igratie en ontwikkeling [People Adrift. Migration and Development] Amsterdam: FreeUniversity.

Hillmann, Felicitas

2005 "Riders on the Storm. Vietnamese in Germany's Two Migration Systems." In A sian M igrants and European Labor M arkets. Edited by Ernst Spaan, Felicitas Hillmann and Ton van $\mathrm{N}$ aerssen. London and New York: Routledge. 
Hugo, Graeme

2003 M igration and D evelopment: A Perspective from A sia. Geneva: IOM.

Hunger, Uwe

2003 Vom Brain Drain zum Brain Gain. Die Auswirkungen der Migration von Hochqualifizierten auf A bgabe und A ufnahmeländer. In G esprächskreis M igration und Integration. Bonn: Friedrich Ebert Stiftung.

Inter-American Foundation (IAF)

2003 'Transnational Communities and Grassroots Development: From Remittances to CoCommunity Development," Statement by David Valenzuela President, Inter-A merican Foundation Subcommittee on Domestic and International M onetary Policy, Trade and Technology House Committee on Financial Services October 1, 2003, http:/ / financialservices.house.gov/ media/ pdf/ 100103dv.pdf, accessed on 21 March 2005.

International Organization for Migration (IOM)

2005b "Förderung der freiwilligen Rückkehr ausländischer Mitbürger," www.bamf.de/ template/ publikationen/ asylpraxis_pdf/ asylpraxis_band_10_131_160.pdf, accessed on 26 May 2005.

2004a Return M igration: Policies and Practices in Europe. Geneva: IOM.

2004b “Migration and Development: Myths and Facts," European Policy CentrelssuePaper No.11 (27.1.2004), IOM, Geneva.

2004c M igratie Info, Special issue on M igration and D evelopment (in Dutch), 10(4):22-23.

2004d The W orld in M otion: Short Essays on M igration and Gender. Geneva: IOM.

2003a "Defining Migration Priorities in an Interdependent World," M igration Policy Issues, No.1, IOM, Geneva.

2003b W orld M igration 2003: M anaging M igration, Challenges and Responses for People on the M ove. Geneva: IOM.

Kalsbeek, Wies

2003 D eKoninklijkeweg. The Hague/ Amerfoort: Cordaid and ICCO. Report prepared for UAF, ISP, Cordaid and ICCO. http:/ / www.uaf.nl/ assets/ uaf/ publicaties/ De\%20koninklijke\%20weg.pdf, accessed on 21 March 2005.

Kindleberger, Charles

1965 Emigration and Economic Growth. Rome: National Bank.

Klaver, Janine

1997 "From the Land of the Sun to the City of Angels: the migratory process of Zapotec Indians from Oaxaca, Mexico to Los Angeles, California." PhD diss., University of Amsterdam. 
Kuptsch, Christiane and Philip Martin

2004 "Nachhaltige Lösungen in der Migrationspolitik." In Kooperation mit der Diaspora. Edited by GTZ. Eschborn: GTZ.

Lacoste, Yves

1989 “Editorial: Geopolitique des diasporas," Hérodote, A vril-Juin, pp.3-12.

Lavenex, Sandra

2004 "Towards an International Framework for Labour M obility? The General Agreement on Trade in Services (GATS)." In O rganisational Recruitment and Patterns of M igration. Edited by Michael Bommes, Kirsten Hoesch, Uwe Hunger and Holger Kolb. Special Issue IMIS Beiträge 25. Osnabrück: IMIS.

Lewis, J. R.

1986 "International Labour Migration and Uneven Regional Development in Labour Exporting Countries," Journal for Economic and Social Geography (TESG), 77(1):27-41.

Lowell, Lindsay and Allan Findlay

2002 "Migration of Highly Skilled Persons from Developing Countries: Impact and Policy Responses." International Migration PapersN o. 44, International Labour Office, Geneva.

Melchers, Konrad, Roger Peltzer und Patrick Wurster

2002 “Königsweg der Entwicklungspolitik,"EPD -Entwicklungspolitik, July, 22 - 31.

M igration N ews

2001 “Co-Development," January 2001, http:/ / migration.ucdavis.edu/ mn/ more.php? id $=2326040$, accessed on 21 March 2005.

Moritz, Peter

2005 “Rückkehrmanagement. DasBundesamtals-Zentralstellefür Informationsvermittlung zur Rückkehrförderung" (ZIRF), www.bamf.de/ template/ publikationen/ asylpraxis_pdf/ asylpraxis_band_10_121_130.pdf; accessed on 26 May 2005.

Mundt, Hans Werner

2004 "Entwicklungspolitik mit der Diaspora," E+Z Entwicklung und Zusammenarbeit (Development and Cooperation), 45: 368-371.

Nyberg Sorensen, Ninna

2004 “Migrant Remittances as a Development Tool: The Case of M orocco," IOM Migration Policy Research Working Papers Series No. 2 - June, www.iom.int/ DOCUMENTS/ PUBLICATION/ EN/ remittances_morocco.pdf, accessed on 9June 2005.

Nyberg-Sorensen, Ninna, Nicholas Van Hear and Poul Engberg-Pedersen

2002 The M igration-D evelopment N exus Evidence and Policy Options. Migration Research Series, N o.8. Geneva: International Organization for Migration.

Overlegcentrum voor de Integratie van Vluchtelingen (OCIV)

2001 Terug of terug: een beschrijvend onderzoek van vrijwillige terugkeerprojecten in negen Europese lidstaten. Overlegcentrum voor de Integratie van Vluchtelingen (OCIV) in opdracht van de Koning Boudewijnstichting, Brussels, www.kbs-frb.be, accessed on 21 March 2005. 
Østergaard-Nielsen, Eva K.

2001 "The Politics of Migrants' Transnational Political Practices," Working Paper Series WPTC-01-22. Transnational Communities Programme, Oxford University, http:/ / www.transcomm.ox.ac.uk/ working_papers.htm , accessed on 21 March 2005.

Papademetriou, Demetrios and Philip Martin

1991 The Unsettled Relatuionship. Labor M igration and Economic D evelopment. New York: Greenwood Press.

Penninx, Rinus and Leo van Velsen

1977 A Contribution to the Theory of International M igration: The Export of M anpower from a Rural D istrict in Central Turkey. The Hague, Imwoo/ Nuffic, Remplod project.

Pieke, Frank, Pal Nyiri, Mette Thuno and Antonella Ceccagno

2004 Transnational Chinese: Fujianese M igrants in Europe. Palo Alto, CA: Stanford University Press.

Posthumus, Bram

1996 "Naderekennismaking gewenst: ontwikkelingsorganisatiesaan depraatmet minderheden," Inzet, 5(29):18-19.

Ratha, Dilip

2003 “Workers' Remittances: An Important and Stable Source of External Development Finance." In Global D evelopment Finance 2003. Washington, DC: World Bank.

Royal Dutch Government

2005 V erbanden tussen Ontwikkeling en M igratie (Connection between Development and Migration). Beleidsnotitie9Juli, TweedeKamer, vergaderjaar 2003-2004, 29693, nr. 1.

Rudolph, Hedwig and Felicitas Hillmann

1998 "The Invisible Hand Needs Visible Heads." In The N ew M igration in Europe: Social Constructions and Social Realities. Edited by Khalid Koser and Helma Lutz. London: MacMillan Press.

Sachverständigenrat für Zuwanderung und Integration

2004 M igration und Integration - Erfahrung nutzen, N eues wagen. Berlin.

Saxenian, Anna-Lee

2000 "Brain Drain or Brain Circulation? The Silicon Valley-A sia Connection," M odern A sia Series, Asia Center, Harvard University.

Schipulle, Hans-Peter

1976 A usverkauf der Intelligenz aus Entwicklungsländern? Eine kritische U ntersuchung zum Brain D rain. München: Weltforum Verlag.

Schmelz, Andrea

2004 Bildungsmigranten aus A frika und A sien. Frankfurt am Main: IKO-Verlag.

Schmidt- Fink, Ekkehardt

2004 "Arbeitsmigranten und Boatpeople," A ID , June, Vol. 2. 
Schönwälder, Karen

2004 "Why Germany's Guestworker were Largely Europeans: The Selective Principles of Postwar Labour Recruitment Policy," Ethnic and Racial Studies, 27(2):248-265.

Schönwälder; Karen, Dita Vogel and Giuseppe Sciortino

2004 M igration und Illegalität in Deutschland, Arbeitsstelle Interkulturelle Konflikte und gesellschaftlichelntegration. Berlin: WZB.

Skeldon, Ronald

2004 "More that Remittances Other Aspects of the Relationship Between Migration and Development." Paper of theThird Coordination M eeting on International M igration, N ew York: United Nations Population Division, UN/ POP/ IG/ 2004/, 9 N ovember.

Spaan, Ernst

1999 Labour Circulation and Socioeconomic Transformation: The Case of East Java, Indonesia. Report no. 56. The Hague: NIDI.

Spaan, Ernst and A ard Hartveld

2002 "Socio-Economic Changeand Rural Entrepreneurs in Pre-Crisis EastJava, Indonesia: Case Study of a Madurese Upland Community," Sojourn: Journal of Social Issues in Southeast A sia, 17(2):274-300.

Steijlen, Fridus

2004 "Molukkers in Nederland: geschiedenis van een transnationale relatie," M igranten studies, 20(4):238-251.

Süssmuth, Rita

2004 "Diasporagemeinden und ihre Verbundenheit mit den Heimatländern" Kooperation mit der D iaspora. Edited by GTZ. Eschborn: GTZ.

TACIS

2004 TACIS Central Asia Indicative Programme 2005 - 2006, Adopted by the European Commission on 20 August 2004, http:/ / europa.eu.int/ comm/ external_relations/ ceeca/ tacis/ index.htm, accessed on 21 March 05.

Tassello, Graziano

1986 "Return Migration in Mediterranean Basin Countries: An Overview of the Literature." In R eturning M igrant W orkers: Exploratory Studies. Asian Population Studies Series, No. 79. Bangkok: UN/ ESCAP.

Tränhardt, Dietrich

2005 Entwicklung durch Migration. egora.uni-muenster.de/ pol/ personen/ thraenhardt/ bindata/ 0405entwicklung_durch_migration.pdf, accessed on 29 May 2005.

Trotzki, Dirk and Robert Schuman

2002 M igration from D eveloping Countries into the EU, Luxemburg: Development Series Working Paper DEVE 107EN, European parliament, Directorate-General for Research.

Turner, William, Claude Henry, Medoune Gueye

2003 "Diasporas, Development and ICTs." In Diasporas scientifiques : Comment les pays en développement peuvent-ils tirer parti de leurs chercheurs et de leurs ingénieurs. Edited by Remi Barré, Valeria Hernandez, Jean-Baptiste Meyer and Dominique Vinck. Paris: Institutefor Research on Development Report(IRD), http:/ / www.limsi.fr/ Individu/ turner/ DKN/ indexDKN.htm, accessed 21 March 2005. 
Unabhängige Kommission Zuwanderung

2001 Zuwanderung gestalten - Integration fördern. Berlin.

United Nations

1997 International M igration and D evelopment: The ConciseR eport. N ew York: United N ations.

Waldinger, Roger and David Fitzgerald

2004 “Transnationalism in Question," A merican Journal of Sociology, 109(5):1177-1195.

Wets, Johan

2004 "Some thoughts about Migration and Development," European Policy Centre Issue Paper No.11, http:/ / www.theepc.net/ TEWN/ pdf/ 863656332_EPC\%20lssue\%20 Paper\%2011\%20\%20M igration\%20and\%20Development.pdf, accessed on 9June2005.

Wickramasekara, Piyasiri

2003 Policy Responsesto Skilled migration: Retention, Return and Circulation. Perspectives on Labour Migration." Paper N o. 5E, International Migration Programme, International Labour Office, Geneva. 